\title{
Relevance Of Devidend Policy As The Mediation On The Relationship Between Financial Performance And Debt On Share Prices
}

\author{
Irma Tyasari ${ }^{1}$, Supami Wahyu Setiyowati ${ }^{2}$ etc2 \\ ${ }^{1}{ }^{2}$ Fakultas Ekonomika dan Bisnis, Universitas PGRI Kanjuruhan Malang, Indonesia
}

OPEN ACCESS

ISSN 2528-4649 (online)

ISSN 2338-4409 (print)

Reviewed by:

Dr. Putu Anom Mahadwartha, S.E,

M.M.,

${ }^{*}$ Correspondence: Irma Tyasari

irmatyasari@unikama.ac.id

Received: November 29, 2020

Accepted: February 20, 2021

diterima Published: March 31, 2021

JBMP: Jurnal Bisnis, Manajemen

dan Perbankan.

Vol: $7 /$ No. 1

doi: 10.21070/jbmp.v7i1.1292
The investors place great importance on the share price of publicly traded companies since it may reflect the company's value. The research objective is to examine the relationship between financial performance and debt at share prices through dividend policy. The method of the research used is quantitative and correlational research. The data analysis technique is the use of smart PLS. The results of the study explain that financial performance has a positive effect on stock prices in the mediation of dividend policy. Debt negatively affects share price mediated by dividend policy. The implication of the study is that companies should consider the benefits as well as risks of borrowing funds from third parties. Investors and potential investors before investing their money in stocks must pay attention to financial performance, corporate debt and dividend policy so that they do not experience losses in their investment.

Keywords: Financial Performance, Debt, Stock Price, Dividend Policy 


\section{INTRODUCTION}

The investors place great importance on the share price of publicly traded companies since it may reflect the company's value. It means that stock/share price is essential components for go public companies. Share price is cash inflow obtained by shareholders and investors in the future. Companies with high share prices indicate high company value in market, both macro and micro market. Thus, the everage stock price of a country increases, indicating that the economy is streghtening. The everage of Indonesian stock price is published on the Indonesian composite stock piece index or IHSG.

Financial performance or rentability could be a factor mediated the stock prices. It defines the company's ability to generate profit within a certain period of time. According to (Kasmir 2016), the ratio to assess the company's ability to analyze profits in a certain year. The rentability describes the capability of the company to create profits through resources such as sales activities, cash, capital, employees, branch offices and etc.

The company debt is an indicator that affects the stock price. The company's ablity to pay debt on time is an achievement in itself. A good debt repayment ratio shows the financial health of the company. A healthy company will obtain trust of both, the bank and the public. The ability to pay debt well is the signal for investors and potential investors to invest in the company by buying their shares.

Devidend policy is a policy implemented by the management to share the company profits with shareholders in a regular basis. The percentage dividend distribution is in accordance with the percentage of the shareholders ownership. This policy is also a signal for investors and potential investors for the future prospect and performance of the company. Commonly, profitable company will pay dividend. Good performance is reflected in the increase in stock price after the company's announcement of dividend distribution.

There are conducted researches related to financial performance and debt to share prices. (Djazuli 2017), the result of the research shows that the proxies for the financial performance of ROE and PER affects stock prices. The research's result of (Handayani 2018), explains that the financial performance using ROE affects stock prices. (Puspitaningtyas 2017) mentions that the financial performance using ROE as a proxy, does not affect stock process. While a reseach conducted by (Handayani 2018), shows debt proxied by DER does not affect share prices. (Puspitaningtyas 2017), explains another result that the copany's debt that is proxied by CR does not affect the share price. (Lapian and Dewi 2018), mentions that the leverage has negative affefts on share prices, while dividend and financial performance have positive affects on them.

The gap of the current study compare to the previous research is the dividend policy variabel as mediating variabel. Based on the background, the research problem of this study: is there any relationship between the financial performance and debt on share prices in the mediation of dividend policy.

\section{METHOD (FOR RESEARCH ARTICLE)}

This study uses quantitative method. It places at the investment gallery of Universitas PGRI Kanjuruhan Malang. The population of the study is all manufacturing companies listed on IDX for the period 2017 to 2019. The sample technique used is the purposive sampling approach, namely the selection with certain judgements and criteria.

\section{Data Research}

Data reseach used is quantitative data, which is the type of data that can be measured or calculated directly, in the form of numbers. It used financial information for manufacturing companies listed on IDX for the 2017 to 2019 period.

\section{Data Collection Technique and Analysis}

The data collection technique is documentation. Researcher collects secondary data such as financial statements of manufacturing companies on the IDX. Data analysis used is Smart PLS which consists of an outer model in testing validity and realibility. The inner model used to measure R2, hyphotesis testing and mediation testing.

\section{Research Variables}

The research variable comprises dependent variabel on stock prices, the independent variable is financial performance proxied by ROE, debt proxied by DER and dividend policy as mediation variable.

\section{RESULTS AND DISCUSSION}

\section{[Table 1 about here.]}

Based on the result of the outer loading test, it shows that the value of outer weight 1 shows that the data of this study are valid and reliable.

In PLS model, the coefficient value of endogenous variable in the Goones of fit of model test are in Table 1 below.

\section{[Table 2 about here.]}

The calculation explains the predictive-relevance value 0,709 or $70,9 \%$. The predictive relevance value $70,9 \%$ reports the information contained in the data $70,9 \%$ can be explained in the model.

\section{Hypothesis Testing and Direct Effect Path Coefficients}

The test results on the direct influence between variables can be seen on the path coefficient value, $t$ statistical test and $p$ value which are presented in Table 3: 
[Table 3 about here.]

[Table 4 about here.]

[Figure 1 about here.]

\section{Discussion}

\section{Financial Performance Affects Stock Prices}

The result concurs that the financial performance had a positive effect on stock prices. Manufacturing companies in 2017-2019 have optimized financial performance. Optimal financial performance is reflected in an increase in share prices. This proves that the value in finance directly affects stock price movement in the market. Stock price is an essensial aspect of investment. The result of this study is in accordance with the signalling theory. A good financial performance has a direct affect on stock prices, giving positive signals to investors or potential investors, in order to invest in the company.

This study is inline with the research conducted in Indonesia by (Djazuli 2017) dan (Handayani 2018). The result of their research report that financial performance has a positive effect on share prices. (Barakat 2014), the same result conducted in Saudi, stated that the financial performance effect positively on stock prices. However, this contradict with the research which was performed in Indonesia by (Handayani 2018) dan (Puspitaningtyas 2017). The result showed that financial performance has no effect on share prices.

\section{Debt Affect Stock Prices}

Debt has negative effect on share prices. Manufaturing companies in Indonesia for the period 2017-2019 have unhealthy debt period. The debt ratio is greater than the assets. Thus, this has an impact on share prices. The higher the debt, the lower is the share price. An increase in debt may give a signal to investor and potential investor too. The potential investor will receive a good signal if they consider that the company is developing and expanding it. The company shall be due care in deciding rhe debt policy, since it may impact the share price. The investor's decision on investment will consider more on the size of company's debt.

This study supports the research performed by (Lapian and Dewi 2018), mentioned that the laverage has negative effect on prices in Indonesia. Similarly, Bahreini at al (2013) conducted reseach in Tehran's Stock Market shows he same result. This indicates that the increase in debt each year will hae adverse impact on share prices. They argue the result of research conducted in Indonesia by (Handayani 2018) dan (Puspitaningtyas 2017). It shows that the debt has no impact on share prices.

\section{Devidend policy affects stock prices}

The dividend policy may have positive affect on share prices. Manufacturing companies in Indonesia for the period of 2017-2019, distributed dividend and cause impact on increasing share prices. The amount of disteibuted devidends based on its company policy. According to (Brigham and Houston 2014), Optimal dividend policy may define as a policy that produce a balance between current dividend and the future growth on maximizing the company's share prices.. While optimal stock price indicates the optimal company value. In line with the signalling theory states that dividend distribution may signal the increased-on stock prices. The increase on stock prices will also increase the welfare of investors.

In some of similar related studies, (Lapian and Dewi 2018), (Sharif, Purohit, and Rekha 2015), conducted in Malaysia, (Asif, Rasool, and Kamal 2011), conducted in Pakistan, mentioned that the devided affect the share prices.

\section{Financial Performance Affects the Devidend Policy}

The financial performance has positive affect on dividend policy. The improvement on financial performance may increase the amount of distributed devidend. The positive affect of financial performance on dividend policy is also in accordance with the signalling theory. Thus, distributed devideds is a signal to show that the profit of the company is increased.

(Wijaya et al. 2010), mentions that financial performance has positive influence on dividend policy. The result is argued by (Asif et al. 2011) that financial performance or profit has no affect on devidend policy.

\section{Debt Affects Devidend Policy}

Debt has negative affect on dividend policy. Company may distribute the less amount of dividend if the it has bigger portion on debt. This issue reveals in manufacturing companies for the 2017-2019 period. The amount of devidend's distribution was influenced by the amount of debt. The result of the study supports the Pecking Order Theory.The company may consider to use internal funding (from profit) rather than external funding.

Researched conducted in Karachi Stock Exchange Pakistan and (Wijaya et al. 2010) mentions that debts has negative influence on dividend policy.

\section{Financial Performance Affects Stock Prices and Mediated by Devidend Policy}

The financial performance has a proven influence on stock prices which is mediated by dividend policy. The total effect is greater than the direct effect. The financial performance is the main factor affecting stock prices. It proves that the increased profit shows a rising share prices. This directly shows that the legitimacy of the company has also increased in the society's perspectives. 


\section{Debt Affects Stock Prices Mediated by Devidend Policy}

Debt has a negative affect on stock prices which is mediated by dividend policy is proven. The indirect effect is bigger than the direct effect. It means that the bigger the debt, the smaller the distributed dividend, which will have an impact on the decreasing in share prices. The company shall focus more on their debt to control the stock prices as well as to fulfill the right of the shareholders.

\section{CONCLUSION}

The financial performance has positive affect on stock prices. The better the financial performance, will have an impact on increasing the company share prices. Good financial performance can provide positive signal both for investors and potential investors. Debt negatively affects the share prices. The higher the company's debt, the lower the share prices will be. Devidend policy has positive affect on stock prices. The amount of the dividend distribution will affect the market share prices. The dividend distribution provides a good signal both for investor as well for potential investors. Financial performance has positive affects on dividend policy. Good financial performance may have an impact on dividend distribution. Debt has negative influence on dividend policy. The amount of dividend distribution depends on the size of the company's debt. The bigger the company's debt, the smaller amount of dividend will be distributed. Financial performance affects share prices in the mediation of dividend policy. Good financial performance will have direct impat on increasing share prices and indirectly have an impact on increasing dividend distibution. Debt has negative affect on share prices and not mediated by the dividend policy. An increase in debt may reduce the share price directly, namely in not developing companies, however, indirectly, it does not affect the dividend distribution.

\section{Recommendation:}

Companies should pay more attention to the debt ratio of the company, in order to control the share prices

Both investors and potential investors shall review the company's debt ratio, thus the expected dividend can be realized.

Further researchers who are interested in financial performance and debt to share price's variables, may consider corporate governance as moderating or intervening variable. 


\section{REFERENCES}

Asif, Aasia, Waqas Rasool, and Yasir Kamal. 2011. "Impact of Financial Leverge on Dividend Policy: Empirical Evidence From Karachi Stock Exchange-Listed Companies.” African Journal of Business Management Vol. 5(4).

Barakat, Abdallah. 2014. "The Impact of Financial Structure, Financial Leverage, and Profitability on Industrial Companies Shares Value (Applied Study on a Samples of Saudi Industrial Companies)." Journal of Finance and Accounting 5 (1):55-66.

Brigham, Eugene F., and Joel F. Houston. 2014. Dasar-Dasar Manajemen Keuangan Buku 1 Edisi 11. Jakarta: Salemba Empat. Djazuli, Atim. 2017. "The Relevance of Leverage, Profitability, Market Performance, and Macroeconomic to Stock Price." Jurnal Of Faculty of Economic and Business,.

Handayani. 2018. "Pengaruh Return on Assets (ROA), Leverage, Dan Ukuran Perusahaan Terhadap Tax Avoidance Pada Perusahaan Perbankan Yang Listing Di BEI Periode Tahun 2012-2015.” Jurnal Akuntansi Maranatha Volume 10,.

Harjito, and Martono. 2014. Manajemen Keuangan. Yogyakarta: Ekonosia.

Kasmir. 2016. Analisis Laporan Keuangan. Jakarta: Raja Grafindo Persada.

Lapian, Yosua, and Sayu S. Dewi. 2018. "Peran Kebijakan Dividen Dalam Memediasi Pengaruh Profitabilitas Dan Leverage Terhadap Harga Saham Pada Perusahaan Manufaktur.” E-Jurnal Manajemen Unud Vol. 7, No.

Puspitaningtyas, Zarah. 2017. "Efek Moderasi Kebijakan Dividen Dalam Pengaruh Profitabilitas Terhadap Nilai Perusahaan Manufaktur." Jurnal Akuntansi, Ekonomi, Dan Manajemen Bisnis Vol. 5, No.

Sharif, Taimur, Harsh Purohit, and Pillai Rekha. 2015. "Analysis of Factors Affecting Shares Prices: The Case of Bahrain Stock Exchange.” International Journal of Economics and Finance 7:ISSN 1916971X.

Conflict of InterestStatement:The authorsdeclare that theresearch wasconducted in the absence of any commercial or financial relationships that could be construed as a potential conflict of interest.

Copyright $\odot$ tahun terbit nama belakang and nama belakang. This is an open-access article distributed under the terms of the Creative Commons Attribution License (CC $B Y)$. The use, distribution or reproduction in other forums is permitted, provided the original author(s) and the copyright owner(s) are credited and that the original publication in this journal is cited, in accordance with accepted academic practice. No use, distribution or reproduction is permitted which does not comply with these terms. 


\section{LIST OF FIGURES}

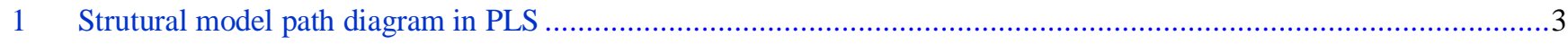




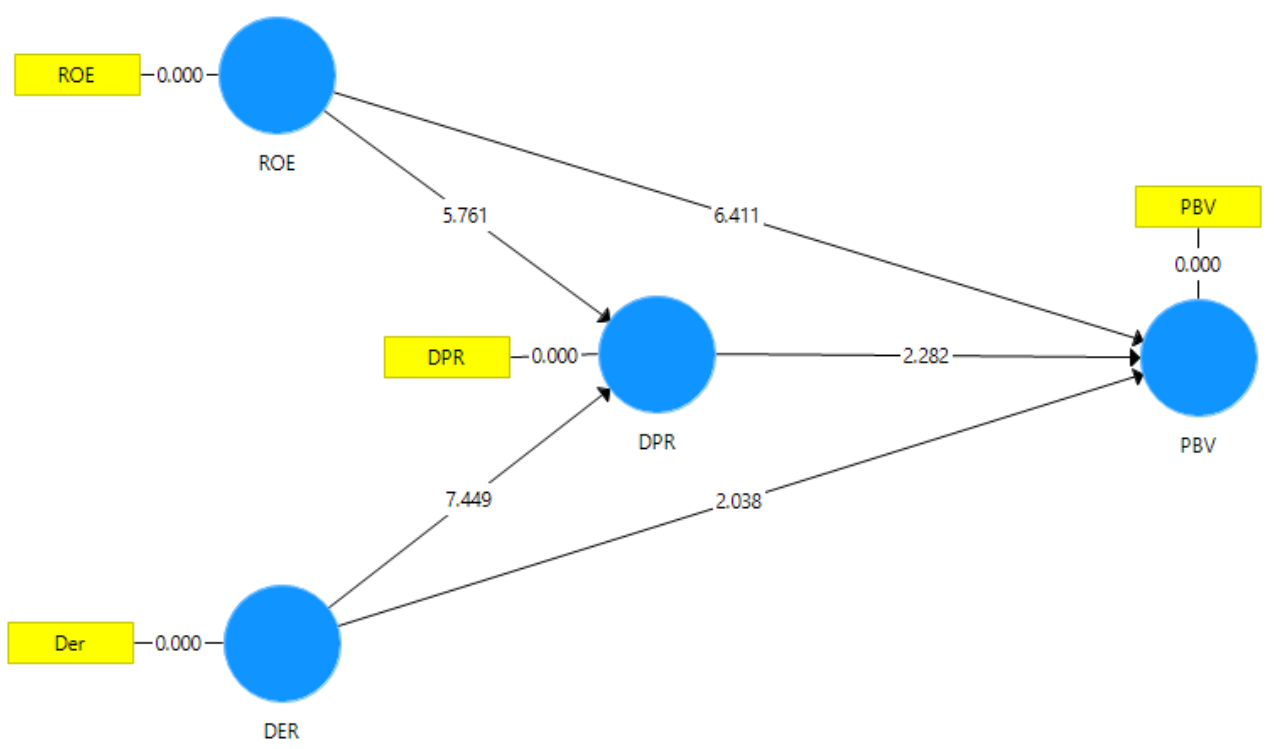

Figure 1 | Strutural model path diagram in PLS 


\section{LIST OF TABLES}

1 The result of testing the outer loading indicator variable stock prices .........................................................

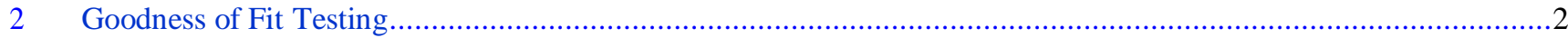

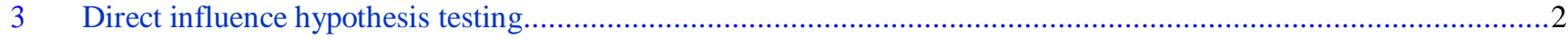

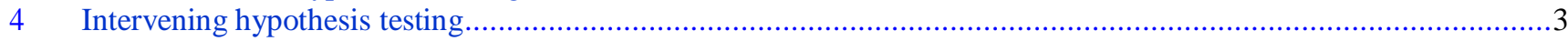


TABLE 1 / The result of testing the outer loading indicator variable stock prices

\begin{tabular}{ll}
\hline Indicator & Outer weight \\
\hline ROE & 1.000 \\
\hline DER & 1.000 \\
\hline DPR & 1.000 \\
\hline PBV & 1.000
\end{tabular}

Source: Analized data (2020) 
TABLE 2 / Goodness of Fit Testing

\begin{tabular}{ccc}
\hline Model & Variabel Endogen & R - Square \\
\hline 1 & DPR & 0,467 \\
\hline 2 & PBV & 0,455 \\
\hline
\end{tabular}

Source: Analyzed data (2020) 
TABLE 3 / Direct influence hypothesis testing

\begin{tabular}{lccccl}
\hline DV & IV & $\begin{array}{c}\text { Path } \\
\text { Coef }\end{array}$ & $\begin{array}{c}\mathbf{t} \\
\text { statis } \\
\text { tics }\end{array}$ & $\begin{array}{c}\text { p- } \\
\text { value }\end{array}$ & Conclusion \\
\hline$D E R$ & $D P R$ & $-0,622$ & 7,449 & 0,000 & Significan \\
\hline$D E R$ & PBV & $-0,290$ & 2,038 & 0,042 & Significan \\
\hline$D P R$ & PBV & 0,352 & 2,282 & 0,023 & Significan \\
\hline$R O E$ & DPR & 0,559 & 5,761 & 0,000 & Significan \\
\hline$R O E$ & PBV & 0,840 & 6,411 & 0,000 & Significan \\
\hline
\end{tabular}

Source: Analized data (2020) 
TABLE 4 / Direct influence hypothesis testing

\begin{tabular}{ccccc}
\hline Variabel & Path Coef & t statistics & p-value & Conclusion \\
& & & & \\
\hline$D E R \rightarrow D P R \rightarrow P B V$ & 0,219 & 2,195 & 0,029 & Intervening \\
\hline$R O E \rightarrow D P R \rightarrow P B V$ & $-0,197$ & 1,989 & 0,047 & Intervening \\
\hline
\end{tabular}

Source: Analyzed data (2020) 
